\title{
Application of Remote Sensing, GIS and Hydrogeophysics to Groundwater Exploration in Ogun State: A case study of OGD- Sparklight Estate
}

\author{
Epuh E.E.*, Jimoh N.O, Orji M.J. and Daramola O.E. \\ Department of Surveying and Geoinformatics, University of Lagos, Nigeria \\ *Corresponding Author: eeepuh@yahoo.com
}

https://doi.org/10.36263/nijest.2019.02.0159

\begin{abstract}
With the increase in population of Ogun state, the necessity to provide water to the populace has become a disturbing problem. In this study, a systematic approach to delineate the groundwater potential zones of the state was carried out using Remote Sensing, Geographic Information Systems (GIS) and Hydrogeophysics as a tool. Vertical Electrical Sounding (VES) observations were also carried out in OGD Sparklight Estate to validate the results obtained from the integrated remote sensing and GIS observation and also determine the aquifer depth and possible pollution. The various thematic maps such as: soil map, land use/Land, geological map, rainfall map, lineaments map were obtained from enhanced satellite imagery and Slope map was generated from Shuttle Radar Topographic Mission elevation model (SRTM DEM). These maps were overlaid in terms of weighed overlay method using Spatial Analysis tool in Arc GIS 10.4. During weighed overlay analysis, different ranks were given to each individual parameter of each thematic map and weights were assigned according to their influence. The groundwater potential map obtained from the study area showed that $47 \%$ of the total study area (Ogun state) lie within the "very high" potential zone, 15\% of the area falls within the "high", 30\% lies within the of "moderate" zone, $5 \%$ lies within the "low "potential zone while "2\% "lies within the very low potential zone. The very high potential areas lie within the sedimentary zone in the southern part of the study area with high alluvial deposits, while the "very low" prospect zone lies majorly within the basement complex zone in the northern part of the study area. The boreholes susceptible to salt water intrusion were identified and the best drilling point with respect to depth were also determined.
\end{abstract}

Keywords: Groundwater, Remote sensing, GIS, Hydrogeophysics, VES

\subsection{Introduction}

Human activities cause changes in groundwater by change in land use/land cover, soil cover, and reduction in groundwater recharge. Although best methods to estimate aquifer thickness and preferable location of borehole are groundwater pumping test/drilling test and stratigraphy analysis, they are cost and time intensive (Moss \& Moss, 1990; Fetter, 1994; Madan et al. 2010; Mukherjee et al. 2012; Mallick et al. 2015). On the other hand, the integration of Remote Sensing, GIS, and geophysical data is a time and cost-effective means of assessing and managing groundwater resources over a large area (Adiat et al. 2012; Verma \& Singh, 2013).

Groundwater prospecting has employed the technology of remote sensing (RS) and geographic information system (GIS) over the years. GIS has become an indispensable tool for handling spatial information for the exploration, development and management of the earth's resources. This method has a significant potential to monitor the information about various phenomena and changes on the earth's surface, such as soil type, land use/land cover, elevation, slope, etc., based on spectral reflectance of earth's surface (Scanlon et al. 2005; Verbesselt et al. 2006; Avtar et al. 2010). 
Several scientific communities have already reported the importance of different hydrogeological factors, viz., geomorphology, geology, land use/land cover, slope, soil cover, lineament density, surface temperature, etc., controlling groundwater potential of any area (Bera et al. 2012; Javed \& Wani, 2009). However, the extent to which they affect groundwater may differ from place and time (Sener et al. 2005; Sreedhar et al. 2009; Avtar et al. 2010). The studies conducted by Godebo (2005), Kamaraju et al. (1996), Sajikumar \& Pulikkottil (2013) and Epuh et al., (2018) have also proven the suitability of GIS and RS techniques for determining potential ground water zones as well as its ability to reduce the time, cost and human power the traditional methods.

Researches have been carried out in the zonation of Groundwater potential using Vertical Electrical Sounding (VES) in some parts of Ogun State such as Egbe-Mopa (Okogbue, et al. 2013), Mowe (Adeoti, et al. 2012), Odeda Local Government Area (Makinde, et al. 2016). Groundwater contamination by toxic metals was assessed for Ifo community of Ogun state where OGD-Sparklight estate is located (Ayedun, et al. 2011). Several settlements in Ogun State such as Abeokuta, Ifo, Odeda, Ewekoro and Owode depend largely on the surface water, which is supplied by the water corporations from Ogun river, Osun river and Yewa river. This source of water supply is not sufficient and therefore does not meet the demand of the populace. For this reason, groundwater should be an alternative source of water which can be mapped using remote sensing and GIS technique through the application of multi-criteria analysis of certain hydrological and geological factors before the actual VES observations for the siting of boreholes and wells Epuh et al., (2018). Hence, this study aims at delineating groundwater potential zones (GWPZs) in Ogun State considering five factors expressed in thematic layers which include lineament, geology, soil texture, slope and land cover

\subsection{Description of the Study Area and its Geology}

\subsection{Description of the study area}

Ogun state is entirely in the tropics. It is located in the Southwest Zone of Nigeria with a total land area of 16,409.26Square kilometers, bounded on the west by the Benin Republic, on the south by Lagos State and the Atlantic Ocean, on the east by Ondo State, and on the north by Oyo and Osun States. It is situated between Latitude $6.2^{\circ} \mathrm{N}$ and $7.8^{\circ} \mathrm{N}$ and Longitude $3.0^{\circ} \mathrm{E}$ and $5.0^{\circ} \mathrm{E}$. The study area is OGD Sparklight Estate, opposite Mountain of Fire and Ministry Headquarters, along Lagos-Ibadan expressway, Ifo Local government Area 74km North of Lagos state.

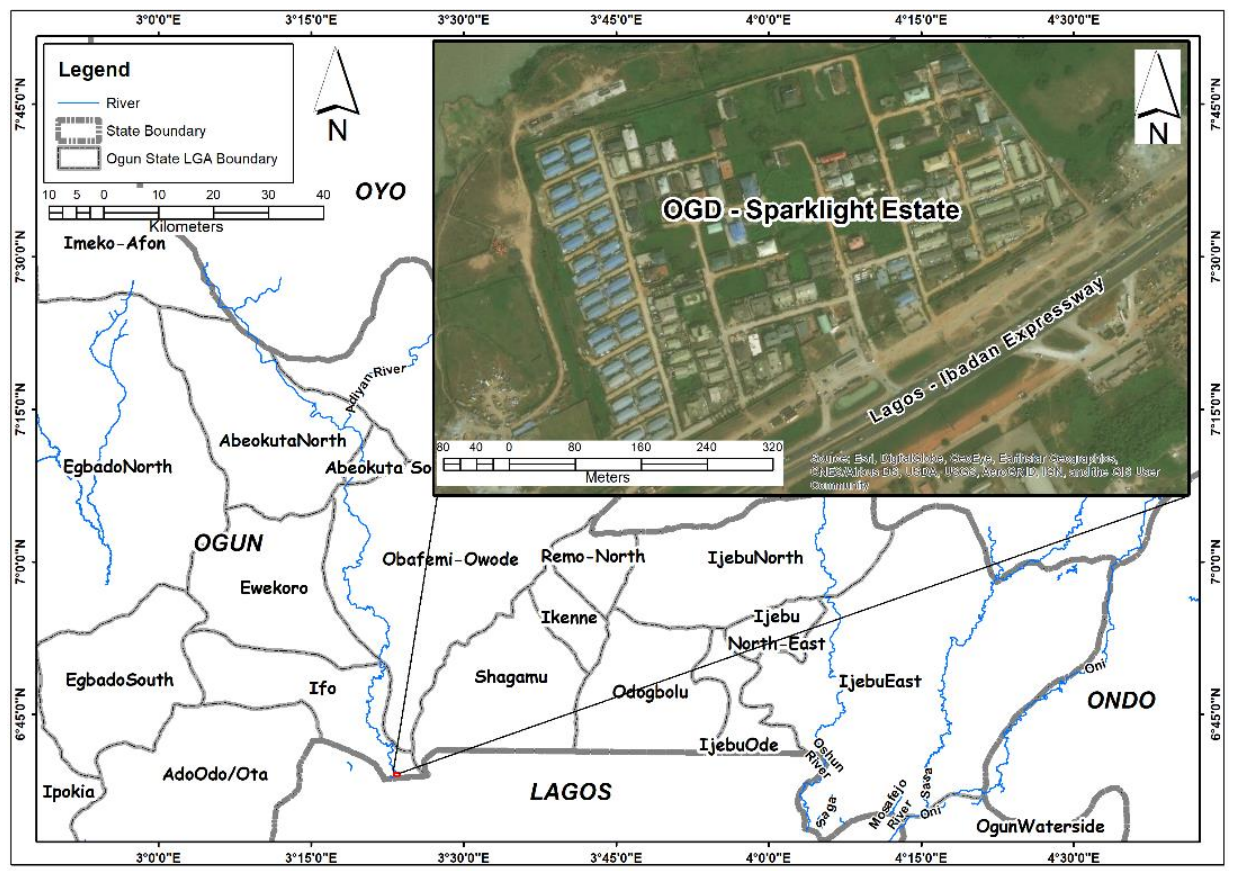

Figure 1: Map showing Ogun State and the study area base map. 


\subsection{Hydrogeology of the study area}

The study area is underlain by part of the sedimentary deposits of south western Nigeria. Generally, it falls within the post-cretaceous parts of Nigeria. The geological sequence expected in the area is Oshosun formation, Akimbo formation, Ewekoro formation and Abeokuta formation. The geology of Ogun State is made up of the basement complex and the sedimentary layers. The basement complex is essentially non-porous and water can only be contained in the cervices of the complex. This basement complex primarily underlines the sedimentary layers which consist of Cretaceous, Tertiary and Quaternary sediments deposited in the coastal basin. The climate is characterized by consistently high temperature ranging between 22 and $35^{\circ} \mathrm{C}$ for most of the year. The South-westerly winds dominate the area between April and October bringing heavy rains and the north-easterlies dominate between November and March bringing dry dusts and harmattan haze in December and January. With no barrier to the prevailing winds, the south westerly wind is able to penetrate deep into the State and beyond bringing a lot of rain. Given the location. Physical Characteristics Ogun state is located in the south-west of Nigeria. The land area is 16,409.26 square kilometers. The eastern basin is made up of mainly of sand, and sandstones, clay limestone. Topography of the State is characterized by high lands to the north and sloping downwards to the south. The highest region is in the north-west and rises to just over 300 meters above sea level. The lowest level is to the south terminating in a long 20 kilometer stretch of the Atlantic Ocean, to the east by Ondo and Osun states, and to the north by Oyo State (Jones \& Hockey, 1964). This bounded on the west by the Republic of Benin, to the south by Lagos State and a chain of lagoons. The only window to the Atlantic Ocean is to the South east of the State in Ogun Waterside LGA. With the general topography sloping from the north to the south, all the main rivers in the state flow from the north to the south. There are five major basins: the Yewa, Ogun, Ona, Osun and Sasa basins.

\subsection{Materials and Methods}

\subsection{Datasets}

Table 1 contains the attribute of the datasets, while Table 2 contains the satellite derived and datasets used for the study. Table 4 contains the assigned Weights and Scores to different Themes and Features respectively

Table 1: Attributes of Datasets

\begin{tabular}{llcccccl}
\hline S/N Image data & $\begin{array}{c}\text { Data } \\
\text { format }\end{array}$ & Epoch & Path/Row & Bands & $\begin{array}{c}\text { Spatial } \\
\text { resolution }\end{array}$ & Data source \\
\hline 1 & Landsat 7 ETM+ & GeoTIFF & 2016 & $190 / 56$ & 8 & $30 \mathrm{~m}$ & https://earthexplorer.usgs.gov \\
2 & Landsat 8 OLI/TIRS & GeoTIFF & 2016 & $191 / 55$ & 11 & $30 \mathrm{~m}$ & https://earthexplorer.usgs.gov \\
3 & Landsat 8 OLI/TIRS & GeoTIFF & 2017 & $190 / 55$ & 11 & $30 \mathrm{~m}$ & https://glovis.usgs.gov \\
\hline
\end{tabular}

Table 2: Datasets Used

\begin{tabular}{llc}
\hline Remote sensing data & Publisher/source & Year \\
\hline Landsat imageries (Path191/ Row 55) & Downloaded from USGS https://earthexplorer.usgs.gov/ & 2016 \\
Rainfall data & Nigerian Meteorological Agency (NIMET) Annual Report & 2016 \\
SRTM DEM & Downloaded from https://earthexplorer.usgs.gov/ & 2018 \\
Geological map & Published by Nigeria Geological Survey Agency (NGSA) & 2004 \\
\hline
\end{tabular}




\begin{tabular}{lll}
\hline Soil map & Published by Soil Survey Division, Fed. Dept. of Agric. 1990 \\
& Land Resources (FDALR) & \\
\hline
\end{tabular}

3.2. Hydrogeophysics

The purpose of Vertical Electrical sounding (VES) is to investigate the changes in subsurface formation resistivity with depth. It shows apparent resistivity (pa) variation with depth with sample use of electric sounding which provides an estimate of the resistivities of the first and last layers and indicates the relative resistivities of intermediate layers. Hence the method is useful in determining and delineation of the aquifer depth. Table 3 shows the acquisition Hydrogeophysics acquisition process.

Table 3: Datasets used

\begin{tabular}{llc}
\hline Hydrogeophysics data & Source & Year \\
\hline Vertical Electrical Sounding and Data & $\begin{array}{l}\text { Primary field data acquired using Vertical Electrical } \\
\text { Sounding Schlumberger array Method. Twelve (12) VES } \\
\text { stations were observed within the study area }\end{array}$ & \\
\hline
\end{tabular}

Table 4: The assigned weights and scores to different themes and features respectively (Source: Epuh et al. 2018)

\begin{tabular}{|c|c|c|c|c|}
\hline $\mathrm{S} / \mathrm{N}$ & Themes & $\begin{array}{c}\text { Weightage } \\
\text { influence (\%) }\end{array}$ & Each class of themes (features) & Score \\
\hline \multirow{3}{*}{1} & \multirow{3}{*}{ Geology } & \multirow{3}{*}{30} & River Alluvium & 10 \\
\hline & & & Amphibole, schist & 8 \\
\hline & & & Sand and clay & 6 \\
\hline \multirow{5}{*}{2} & \multirow{5}{*}{ Rainfall (mm) } & \multirow{5}{*}{22} & $1387-1554$ & 10 \\
\hline & & & $1554-1661$ & 20 \\
\hline & & & $1661-1715$ & 30 \\
\hline & & & $1715-1742$ & 40 \\
\hline & & & $1742-1780$ & 50 \\
\hline \multirow{2}{*}{3} & \multirow[t]{2}{*}{ Soil map } & \multirow{2}{*}{18} & Swamp soils & 40 \\
\hline & & & Reddish Friable Porous Sand & 24 \\
\hline \multirow{3}{*}{4} & \multirow{3}{*}{ Lineament density } & \multirow{3}{*}{15} & $0-1$ & 9 \\
\hline & & & $2-4$ & 18 \\
\hline & & & $5-7$ & 24 \\
\hline \multirow{5}{*}{5} & \multirow{5}{*}{ Slope $(\%)$} & \multirow{5}{*}{10} & $0-2$ & 40 \\
\hline & & & $2-5$ & 32 \\
\hline & & & $5-10$ & 24 \\
\hline & & & $10-17$ & 16 \\
\hline & & & $17-67$ & 8 \\
\hline \multirow{5}{*}{6} & \multirow{5}{*}{ Land cover } & \multirow{5}{*}{5} & Waterbody & 10 \\
\hline & & & Built-up & 8 \\
\hline & & & Wetlands & 6 \\
\hline & & & Vegetation & 4 \\
\hline & & & Bareland & 2 \\
\hline
\end{tabular}

\subsection{Data processing}

The Landsat satellite image, path and row 191/55 was used. Figure 2 shows the flow chart for the project execution. Table 5 shows the classification of the groundwater potential zones. 


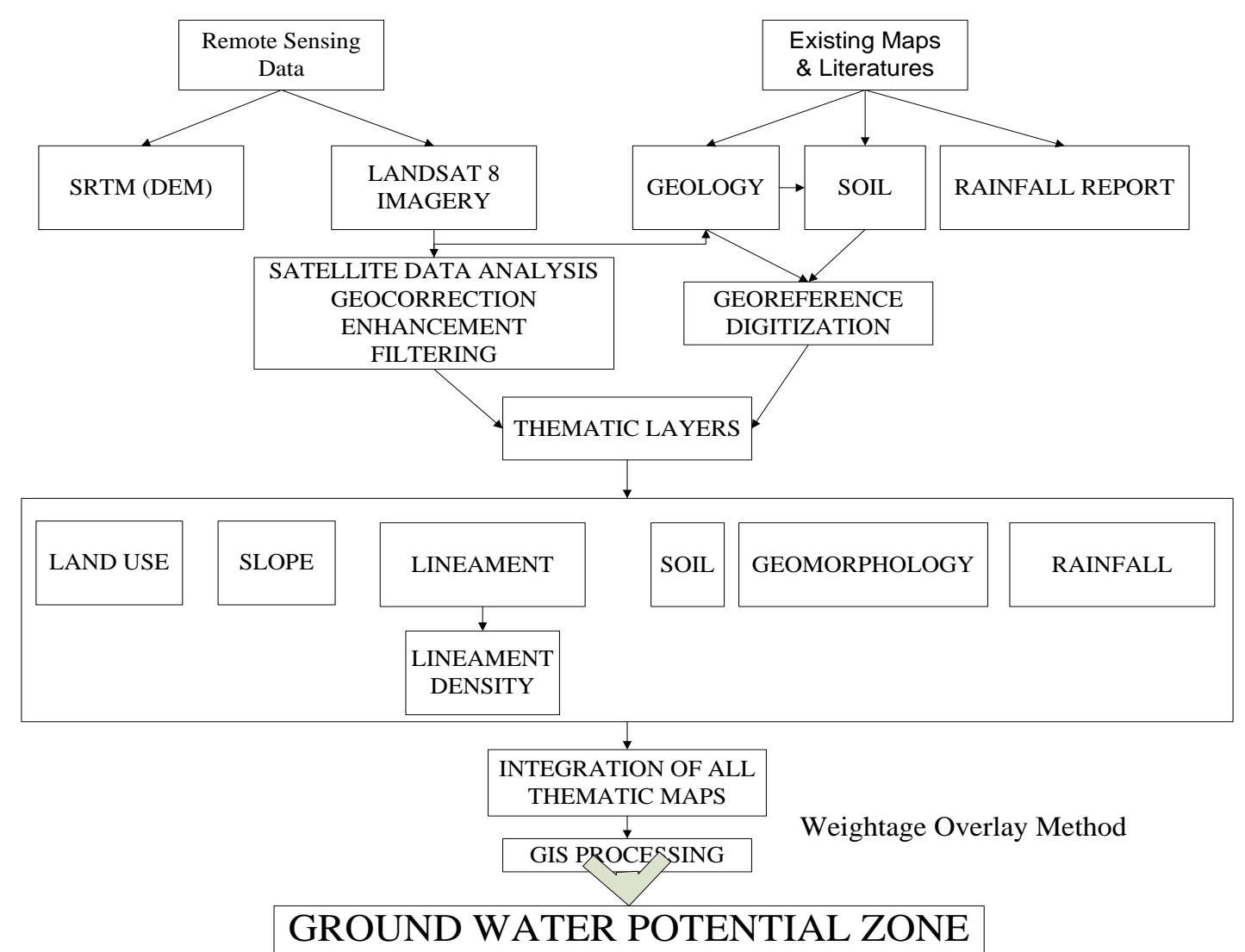

Figure 2: Flowchart for Project Execution

Table 5: Groundwater Potential Zoning

\begin{tabular}{ll}
\hline Zone & Groundwater Category \\
\hline $10-13$ & Very High Potential \\
$9-10$ & High Potential \\
$7-9$ & Moderate Potential \\
$6-7$ & Low Potential \\
$4-6$ & Very Low Potential \\
\hline
\end{tabular}

The weights and rank have been taken considering the works carried out by researchers such as (Krishnamurthy et al. 1996; Saraf \& Chowdhary, 1998). All the thematic layers were converted into raster format and superimposed by weighted overlay method (rank and weight wise thematic maps were integrated with one another through GIS ArcInfo grid environment). For assigning the weight, the geology and rainfall map were assigned higher weight due to their high-water infiltration, whereas the slope and land use/land cover were assigned lower weight. After assigning weights to different parameters, as shown in Table 4, individual ranks are given for sub-variable. Then, each of the individual themes were overlaid one at a time to get the final composite map such that each polygon in the final composite map is associated with a particular set of information of all thematic layers. Also, the evaluation of ground water prospect for each polygon in the output is based on the added values of scores of various themes as described in the Equation 1.

$$
\begin{aligned}
G W P I= & \left(G_{w}\right) x\left(G_{T}\right)+\left(L U L C_{w}\right) x L U L C_{T}+\left(S T_{w}\right) x\left(S T_{T}+\left(D D_{w}\right) x\left(D D_{T}\right)+\left(R D_{w}\right) x\left(R D_{T}\right)+\right. \\
& \left.\left(\mathrm{SL}_{\mathrm{w}}\right) x\left(S L_{T}\right)+L D_{w}\right) x\left(L W_{T}\right)
\end{aligned}
$$


Where GWPI $=$ Groundwater Potential Index, $\mathrm{G}=$ Geology, LULC $=$ Land Use land Cover, ST $=$ Soil, $\mathrm{SL}=$ Slope, $\mathrm{DD}=$ drainage density, $\mathrm{RD}=$ Rainfall Distribution, $\mathrm{LD}=$ Lineament Distribution, $\mathrm{w}$ $=$ weighting coefficient and $\mathrm{T}=$ Thematic Layers .

The range of GWPI values (score value) were divided into five classes (called zones) and the GWPI of different polygons falling under different range were grouped into one class. Thus, the entire study area was qualitatively divided into five ground water potential zones namely; very high potential, high potential, moderate, low potential and very low potential for groundwater as shown in the Figure 10.

\subsection{Hydrogeophysics (VES interpretation, scaling and gridding of geoelectric sections)}

The VES Curves were quantitatively interpreted by partial curve matching using two-layer model curves and the corresponding auxiliary curves. multi-layered field curves were matched segment by segment starting from the small electrode spacing. The theoretical VES curves were generated from partial curve matching interpretation results (layer, thickness and resistivities) using a computer programme based on the inputted data. The field curves were then compared with the computergenerated curves, where a good fit was obtained hetlen a field and computer-generated curve. The scaling and gridding of the geoelectric section involves the construction of a digital file suitable for aquifer reservoir mapping and gridding. The geoelectric sections were digitized with respect to their differential lithostratigraphic thickness. The modules in the reservoir scaling were designed to produce chains of cells for visual representation of beds, bed sets, lamina, and lamina sets in a twodimensional outlook. Each lithologic unit was assigned its own interpreted geologic parameters and this process was carried out in all the fifteen geoelectric sections used in the research. The extended entity relational model was utilized in the creation of the Hydrogeophysics database.

\subsection{Results and Discussion}

\subsection{Results}

\subsubsection{Soil map}

The result of the soil type reveals that the study area is predominantly covered by three main soil types namely: sandy loam is predominant soil group, followed by clay soil group and sandy clay (Figure 3). According to their influence on groundwater occurrence, sandy loam soil is considered as very good, whereas sandy clay is being considered as moderately better than other soil type. Result shows that most part of the study area is covered with sandy loam, which is considered a good groundwater potential zone. The movement and infiltration of water in these three types of soil is not same so based on its property the weightages have been assigned.

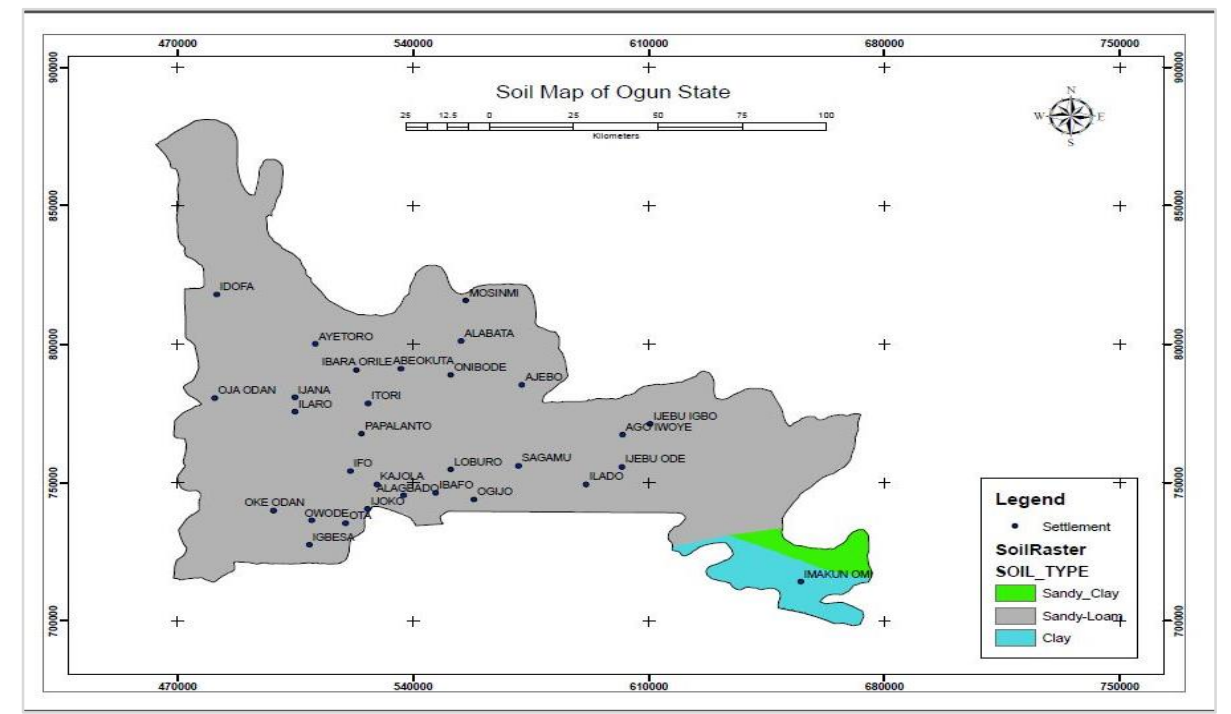

Figure 3: Soil map of Ogun state 


\subsubsection{Slope map}

Slope is one of the important terrain parameters expressing the steepness from the ground surface which provide important information on the nature of geologic and geodynamic processes operating at that regional scale. In general, in the vector form closely spaced contours represent steeper slopes and sparse contours exhibit gentle slope whereas in the elevation output raster every cell has a slope value. Here, the lower slope values indicate the flatter terrain (gentle slope) and higher slope values correspond to steeper slope of the terrain. In the elevation raster, slope is measured by the identification of maximum rate of change in value from each cell to neighboring cells. The slope amount derived from digitized contours and spot heights have shown that elevation decreases from the southern part to the northern part with slope in the study area. Result shows that although slope angle of the study area varies from 0 to 47, most of the part lie within slope angle between 0 and 7 (Figure 4). In the nearly level slope area (0-1) degree, the surface runoff is slow allowing more time for rainwater to percolate and consider good groundwater potential zone, where as strong slope area (30-47) degree, facilitate high runoff allowing less residence time for rainwater hence comparatively less infiltration and poor groundwater potential. The entire slope map is divided into eight categories. Table 6 shows the slope categories.

Table 6: Slope gradient and category

\begin{tabular}{lll}
\hline Class & Percentage & Slope category \\
\hline 1 & $0-7$ & Nearly Level \\
2 & $7-16$ & Gentle Slope \\
3 & $16-30$ & Moderate Slope \\
4 & $>30$ & Steep Slope \\
\hline
\end{tabular}

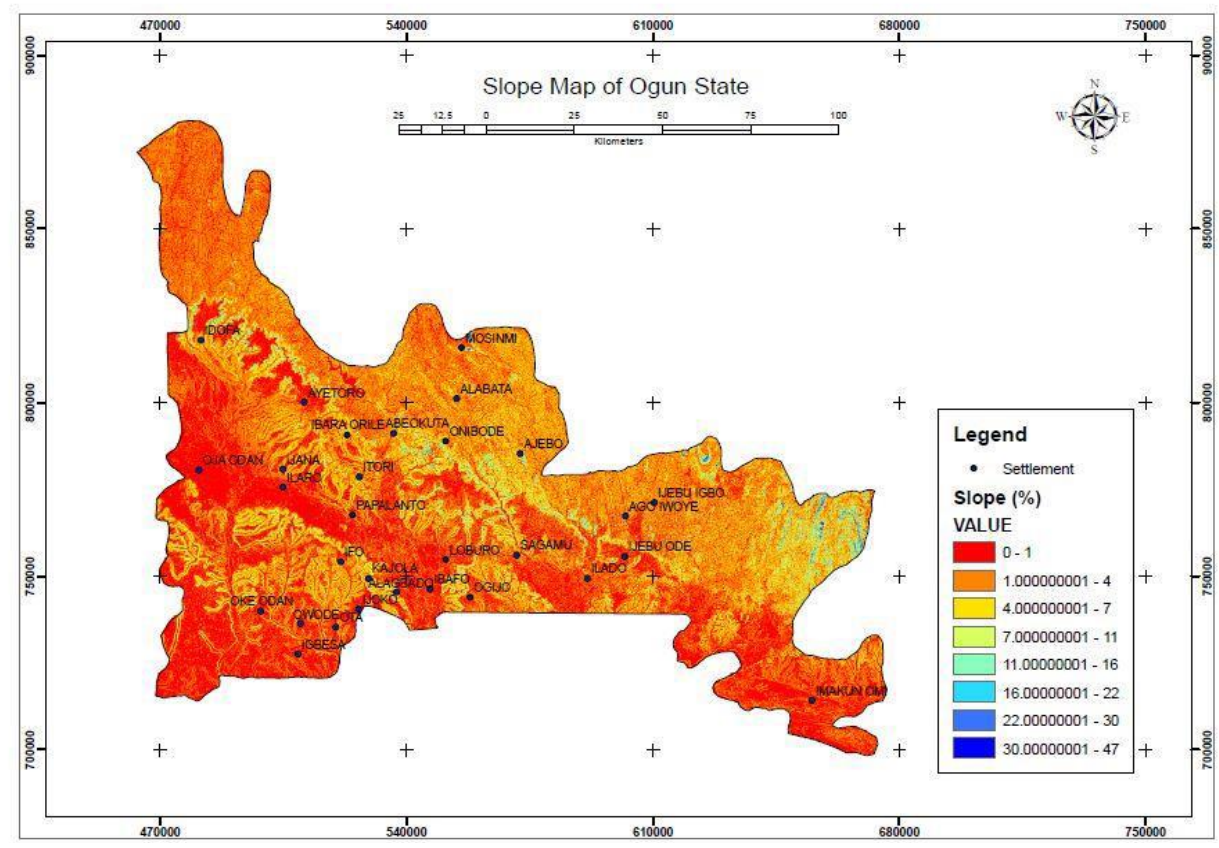

Figure 5: Slope map

\subsubsection{Rainfall map}

The present study has been considering the annual mean rainfall of Ogun state. Figure 6 shows the rainfall map of Nigeria. The area is divided into six ranges which are varying from 1,007-2,519mm. 
The result shows that the study area lies within $1,247-1,474 \mathrm{~mm}$ of rainfall which shows that annual rainfall in the area is moderately high.

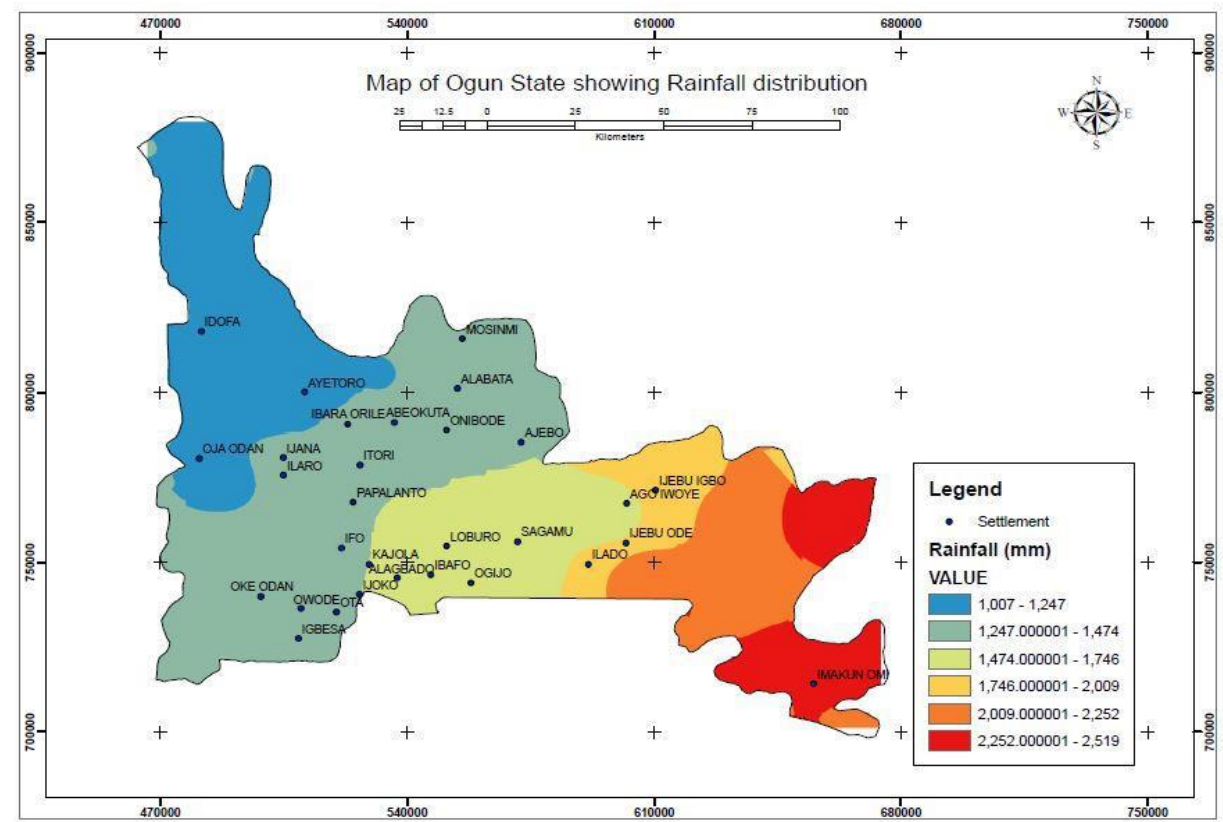

Figure 6: Rainfall Map

\subsubsection{Geology map}

The major rocks found in study area are Alluvial shales, mudstone, silt stone, granites and gneisses. Geology also plays major role in groundwater occurrence in any area. Here, the study area is occupied by six major features such as Alluvial, shales, mudstone, silt stone, granites, and gneisses (Figure 7). Alluvial is the depositional structure formed by running water. Shales are soft finely stratified sedimentary rock that formed from consolidated mud or clay and can be split easily into fragile plates. One is an extremely fine-grained sedimentary rock consisting of a mixture of clay and silt-sized particles. The rocks in the study Area are considered highly good for groundwater occurrence.

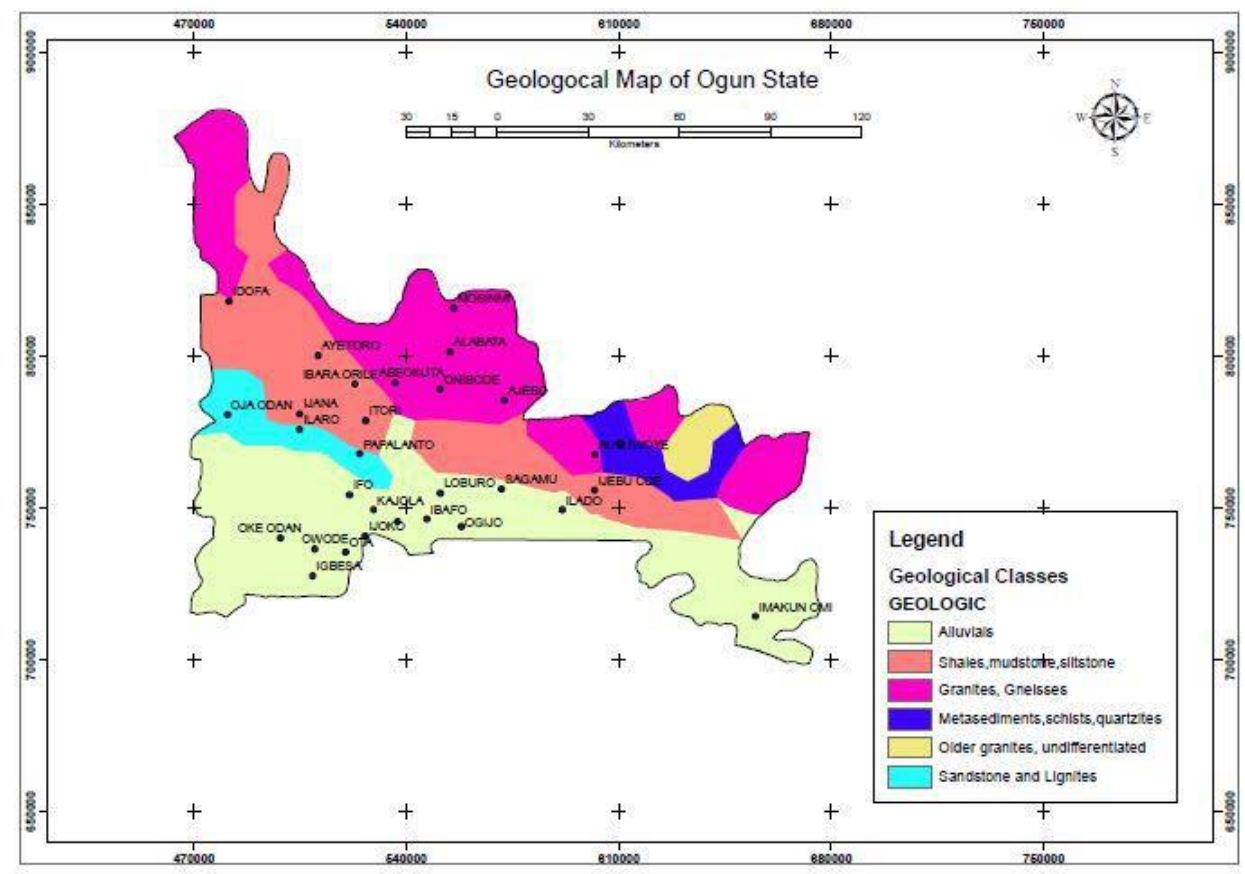

Figure 7: Geological map of the Ogun State 


\subsubsection{Lineament map}

Structural faults (Lineaments) are the irregular earth features that can easily identified on the ground. These feature reveals the surface and underlying structural features. Lineaments are indicators of subsurface faults and fractures influencing the occurrence of ground water acting as canals and reservoirs. Lineament density of an area can ultimately expose the groundwater potential, since the presence of lineaments usually signifies a permeable zone. Areas with high lineament density are good for groundwater potential zones (Haridas et al. 1998). So, the lineaments play a major role in groundwater potential zoning. For the present study 0-7 meters buffers were created from the lineament and suitable weightage have given based on the infiltration of groundwater (Figure 8). Table 4 shows the lineament density classification

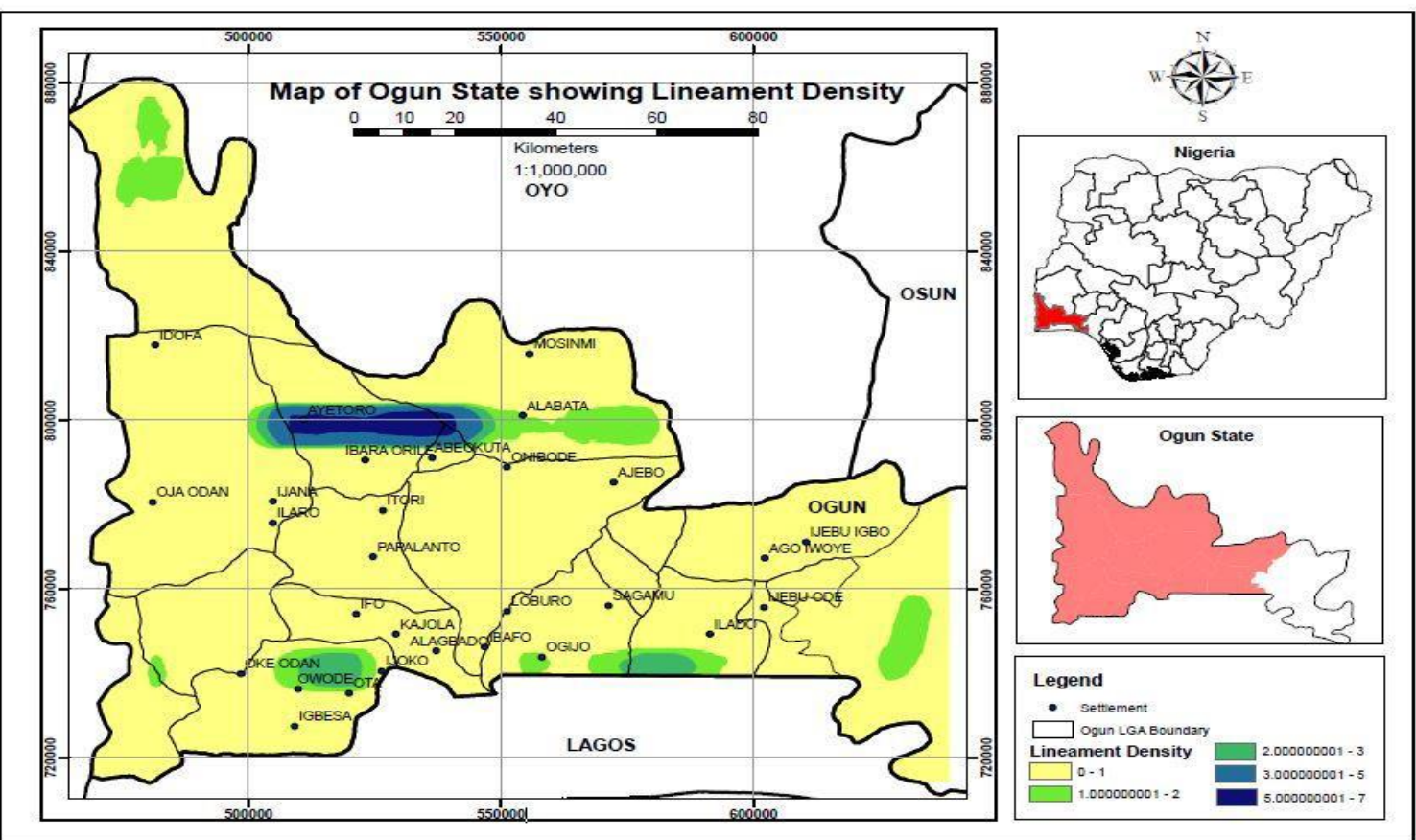

Figure 8: Lineament density map

Table 7: Lineament density classification by weight

\begin{tabular}{ll}
\hline Lineament density & Weight \\
\hline $0-1$ & 20 \\
$1-2$ & 40 \\
$2-3$ & 60 \\
$3-5$ & 80 \\
$5-7$ & 100 \\
\hline
\end{tabular}

\subsubsection{Land cover map}

The surface covered by vegetation like forests and agriculture traps and holds the water in root of plants whereas the built-up and rocky land use affects the recharge of groundwater by increasing runoff during the rain, so it is necessary to study what kind of features are covered the study area's land surface. The Landsat 8 satellite image has been used for the study to find out the land use and land cover of study area. The supervised classification method has been used with level - I classification. The result of the study found the study area is covered by five different classes such as: 
bare land, forest, built-up, water body. This shows that the study area is suitable for ground water exploration. The weight assigned based on water logging and runoff properties of LU/LC (Figure 9).

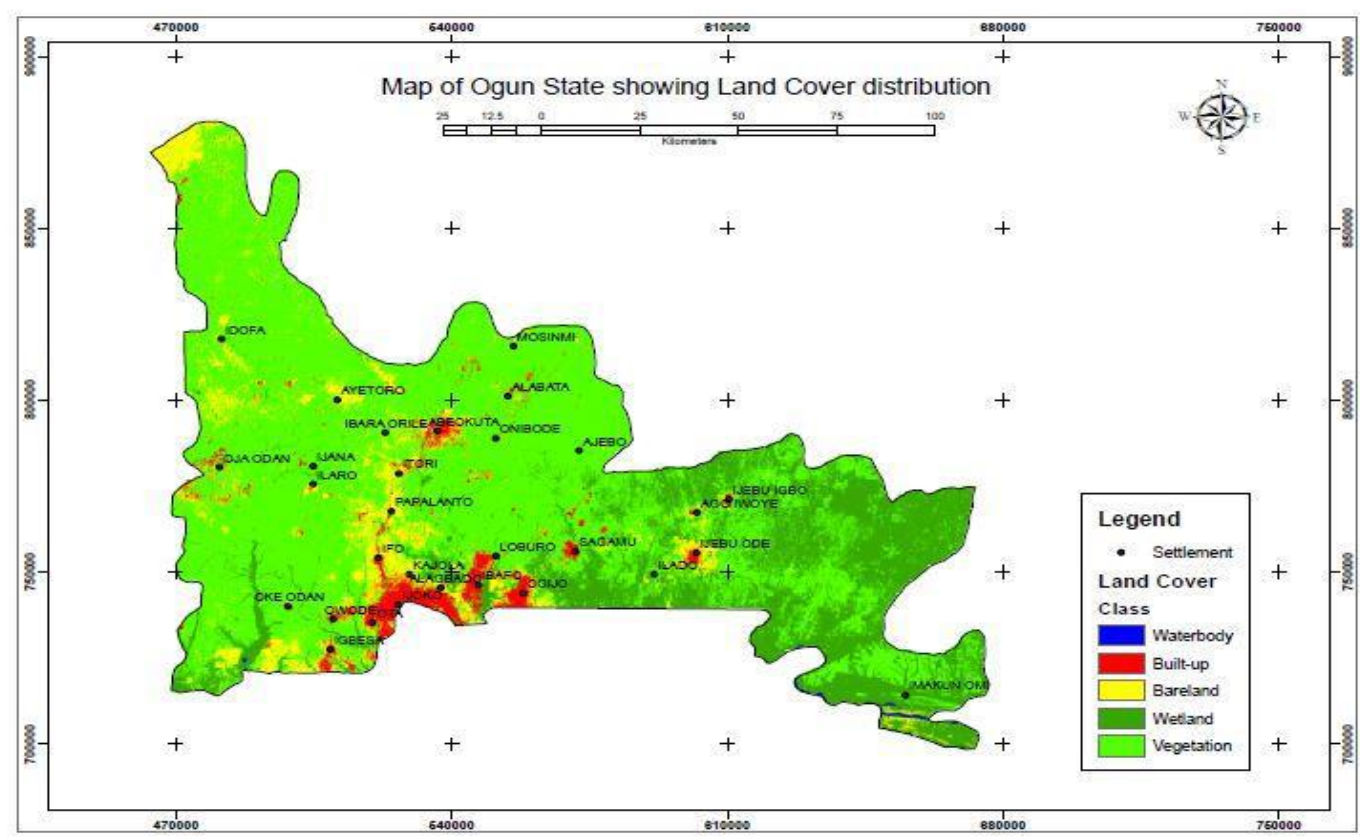

Figure 9: Land Cover Map

\subsubsection{Integration of thematic layers using GIS (weighted overlay method)}

The ground water potential zones were obtained by overlaying all the six thematic maps in terms of weighted overlay method using the spatial analysis tool in Arc GIS 10.4. Integration of thematic layers and modeling through GIS yielded the groundwater potential mapping, which was classified as very high potential, high potential, moderate potential, low potential and very low potential according to Lubang et al. (2008). The result shown in Figure 10 shows that the study area is located at a place of very high ground water potential. Figure 11 shows a bar Chart depicting the percentage of Groundwater Potential distribution of the study area.

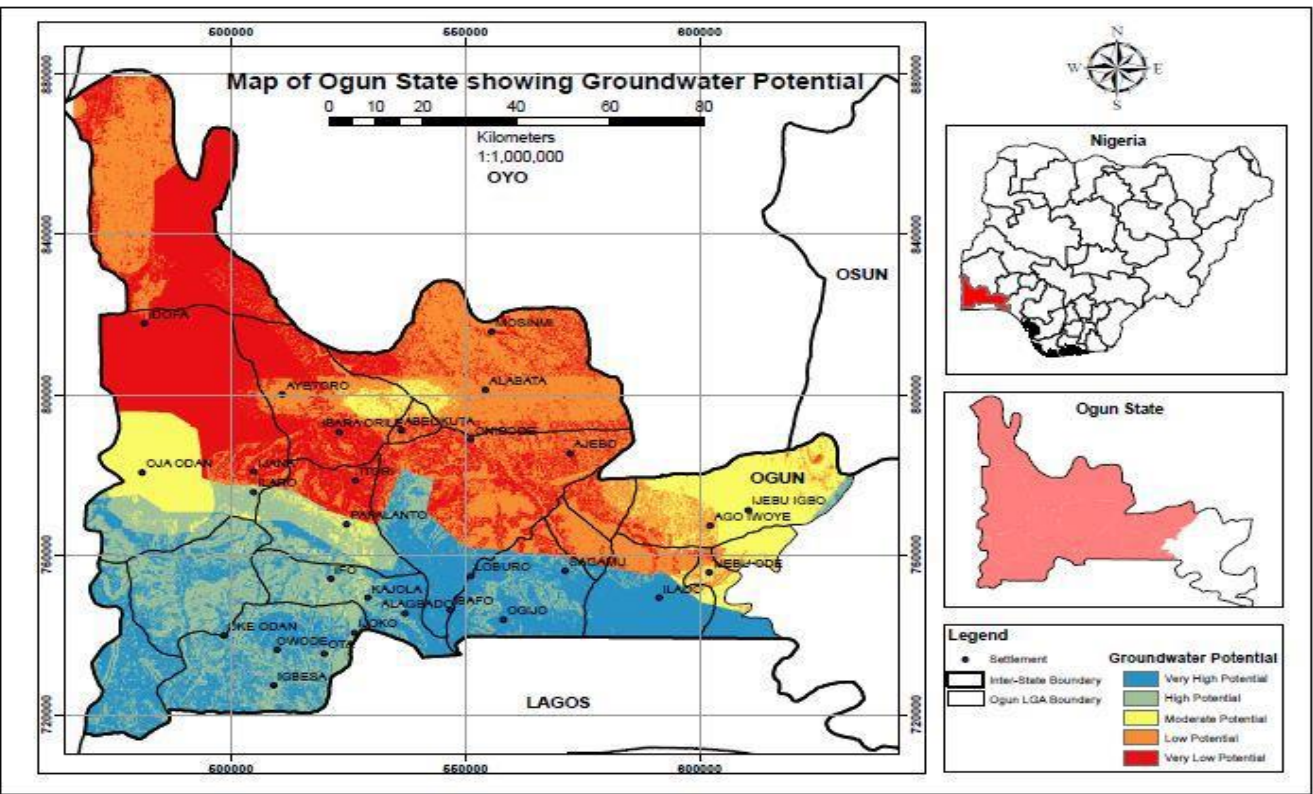

Figure 10: Groundwater potential Map of Ogun State 


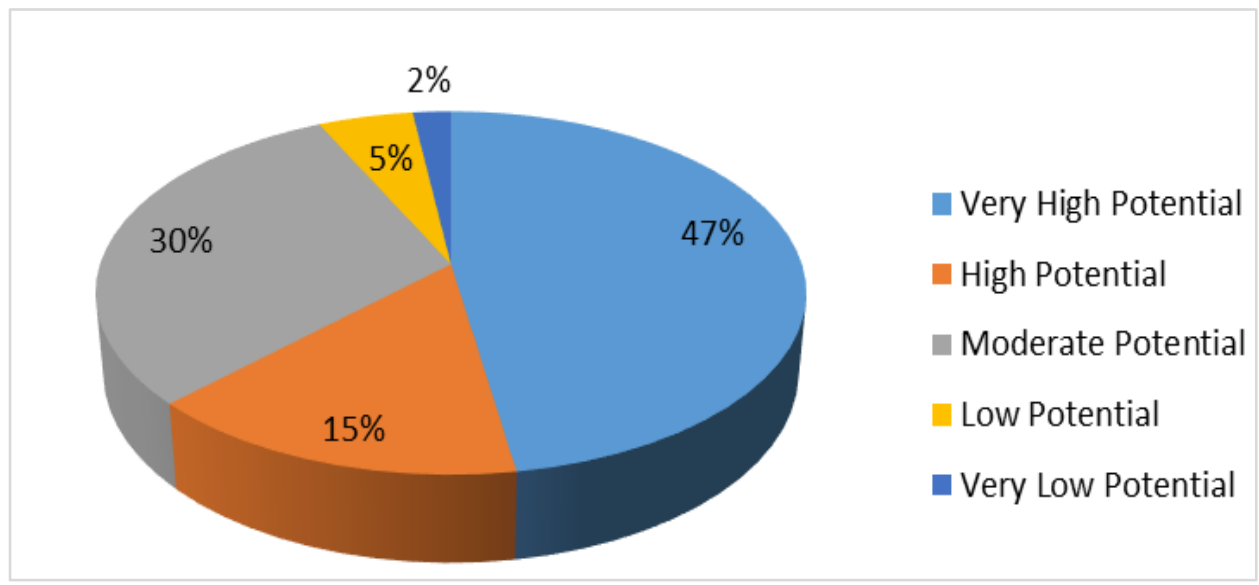

Figure 11: Pie chart showing the Spatial distribution of groundwater potentials in Ogun State in percentage.

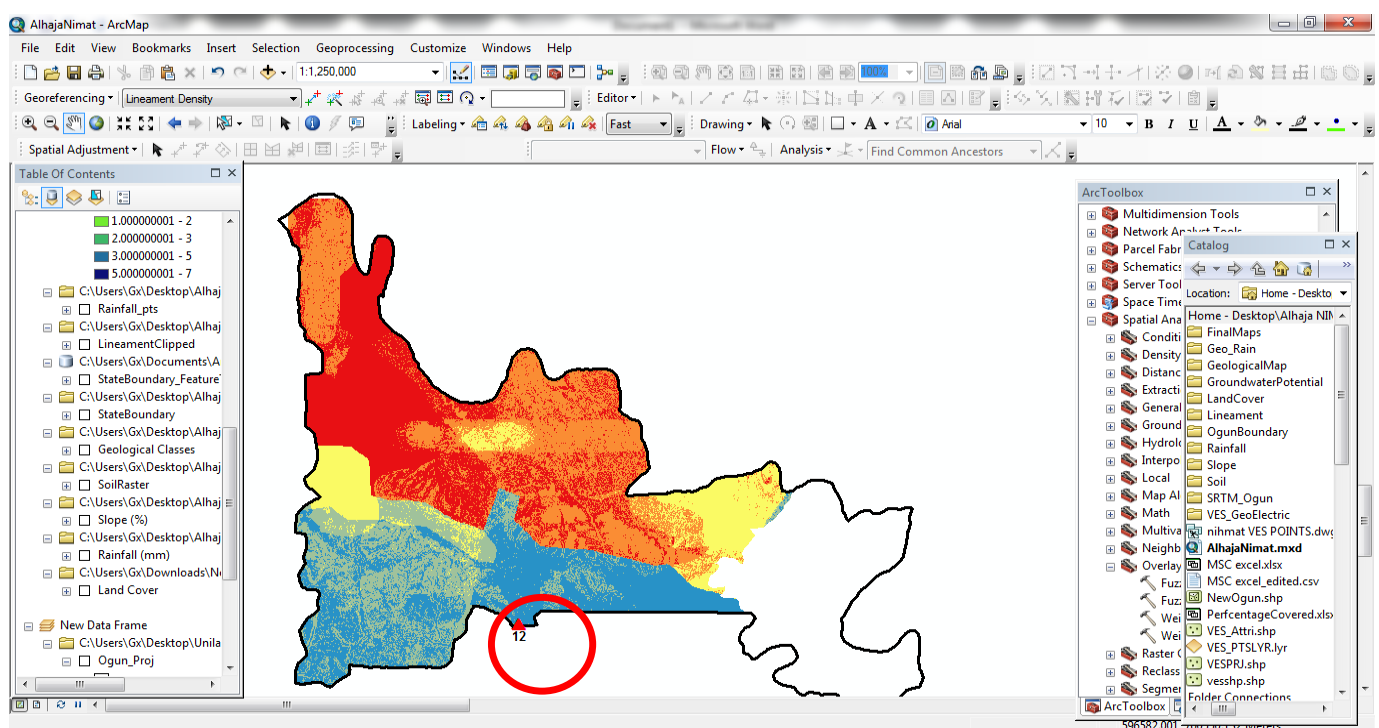

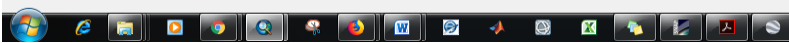

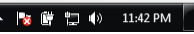

Figure 12: Map showing VES points fall in the area of very high ground water potential

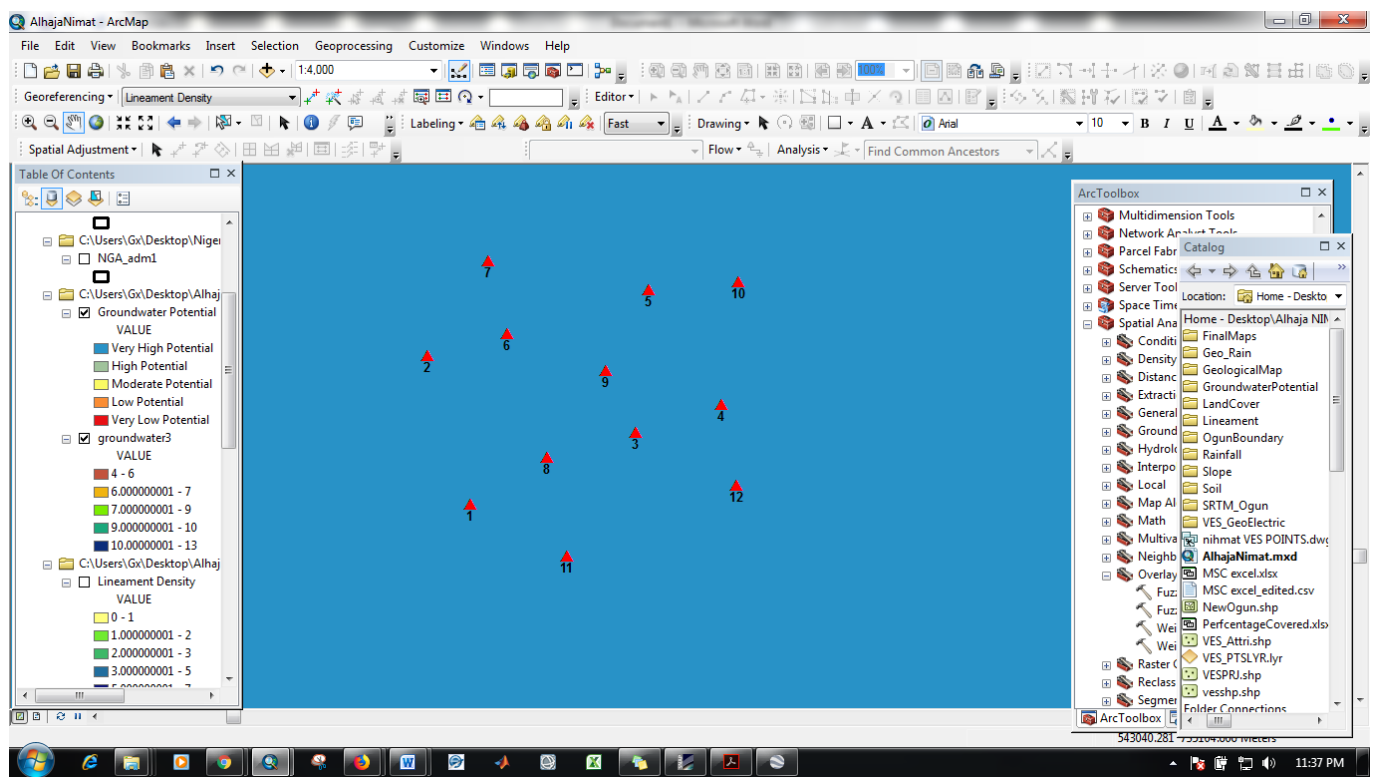

Figure 13: All the VES points fall in the class of 'Very High Potential'. 


\subsubsection{Digitized geoelectrical sections and queries}

The VES points were all located within the low groundwater potential of the study area as shown in Figure 10. The queries were carried out on base map to determine the VES locations with various groundwater conditions. The queries show the location, depth, layer thickness and coordinates. The identified points of the queries on the geoelectric section and base map are shown in yellow colour. The queries include the following:

i. The location and depth for Fresh water (Figure 14)

ii. The location and depth for Brackish water (Figure 15).

iii. The location and depth for Saline water (Figure 16)

iv. The location and depth for Fresh water (Figure 17)

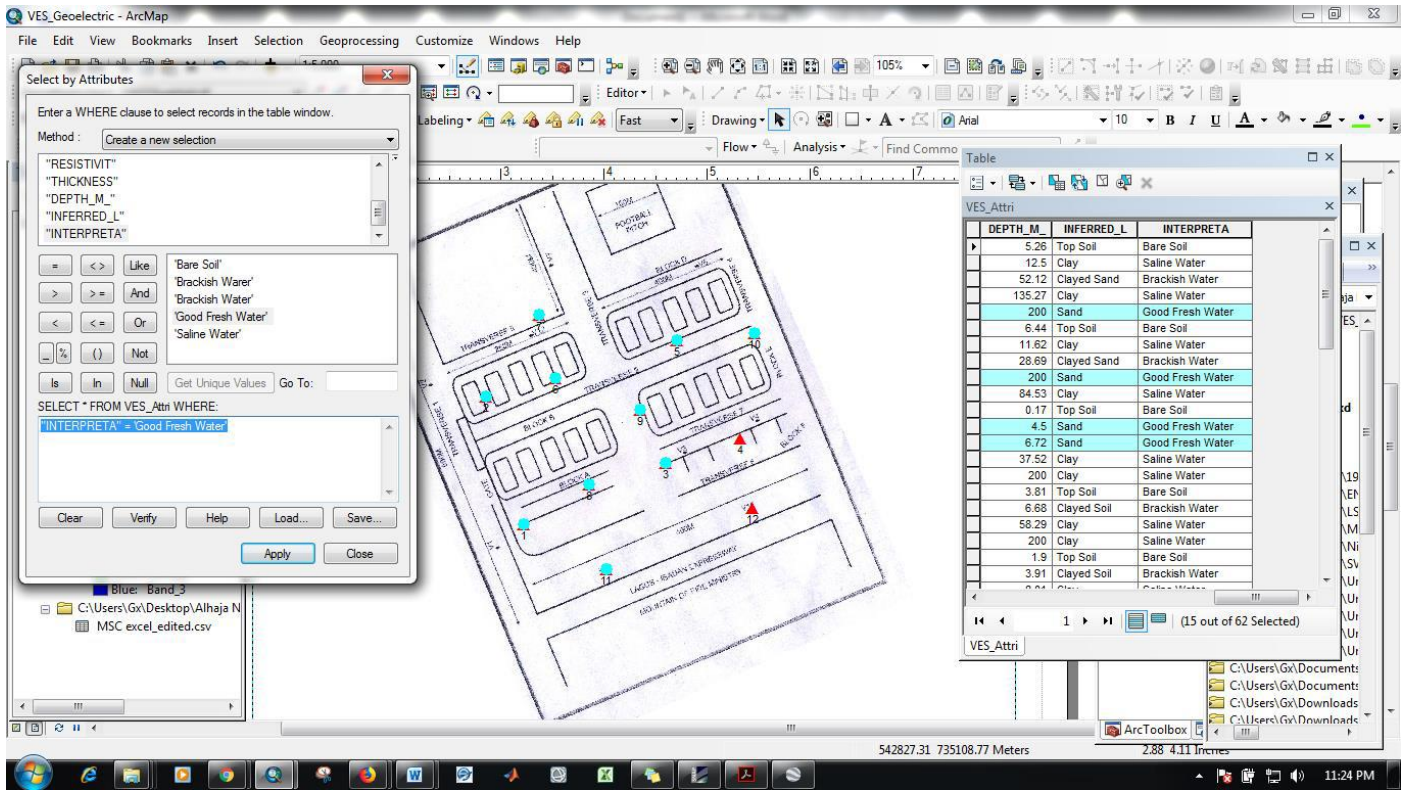

Figure 14: "INTERPRETA" = 'Good Fresh Water' VES points 1,2,3,5,6,7,8,9,10,11

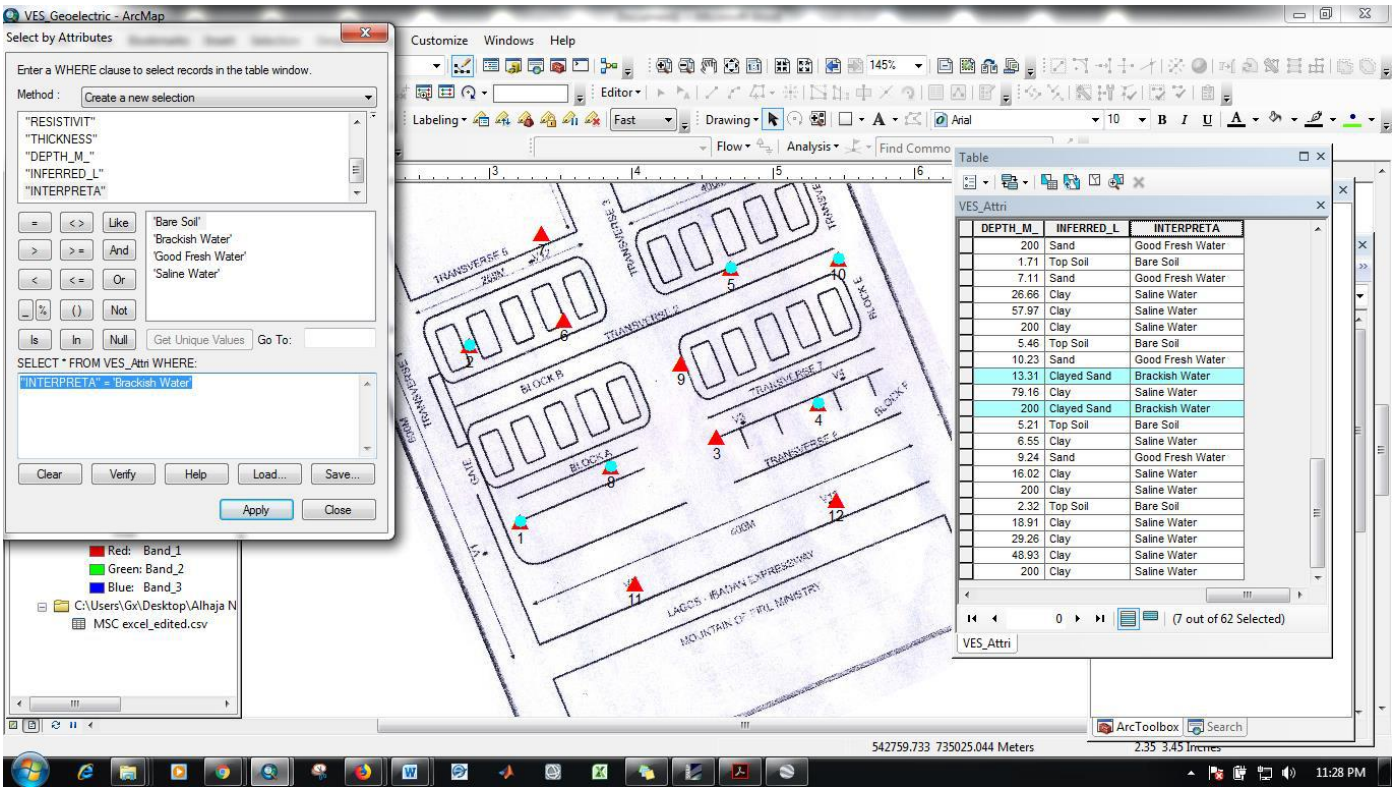

Figure 15: "INTERPRETA" = 'Brackish Water' VES points 1,2,4,5,8,10 


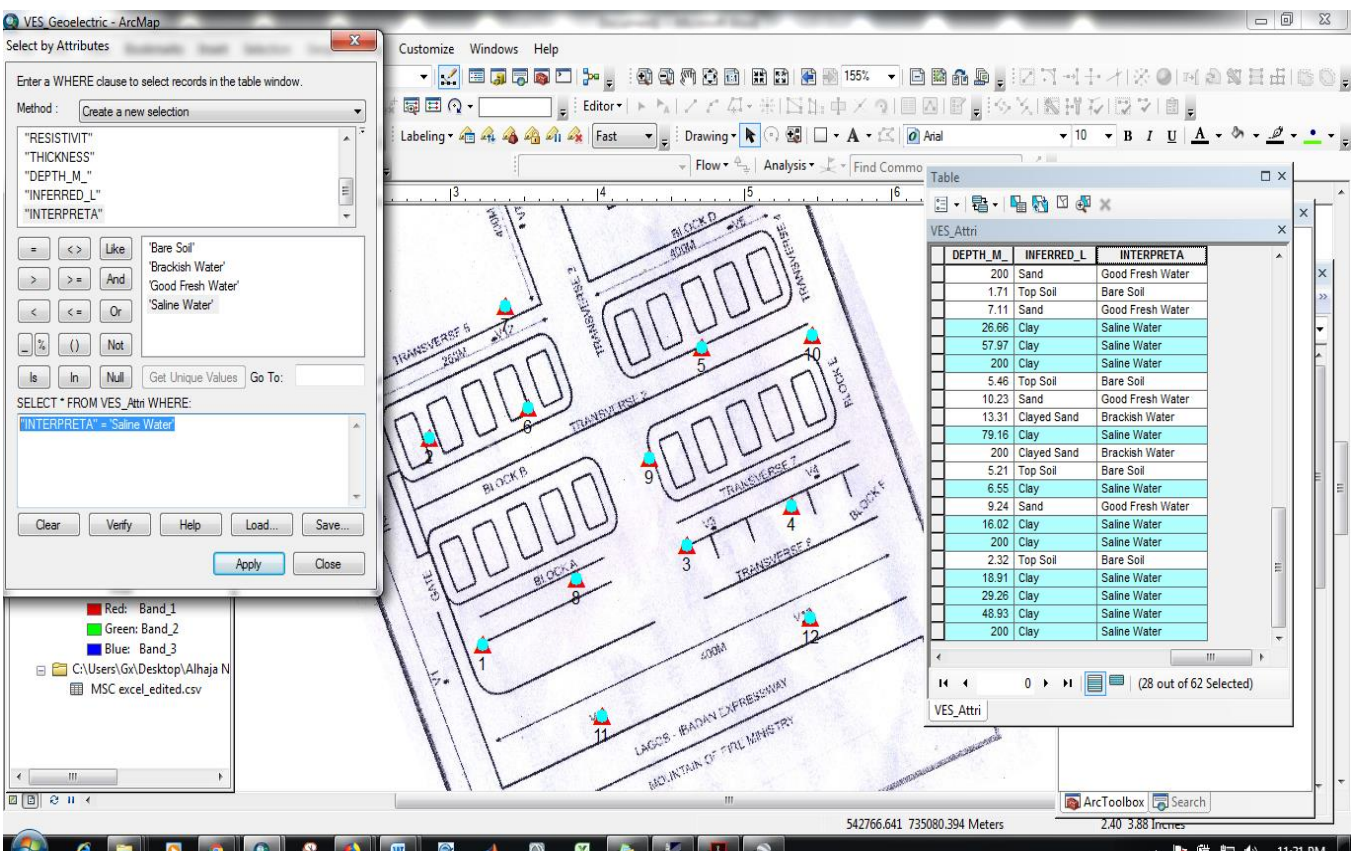

Figure 16: "INTERPRETA" = 'Saline Water' VES points 1,2,3,4,5,6,7,8,9,10,11,12

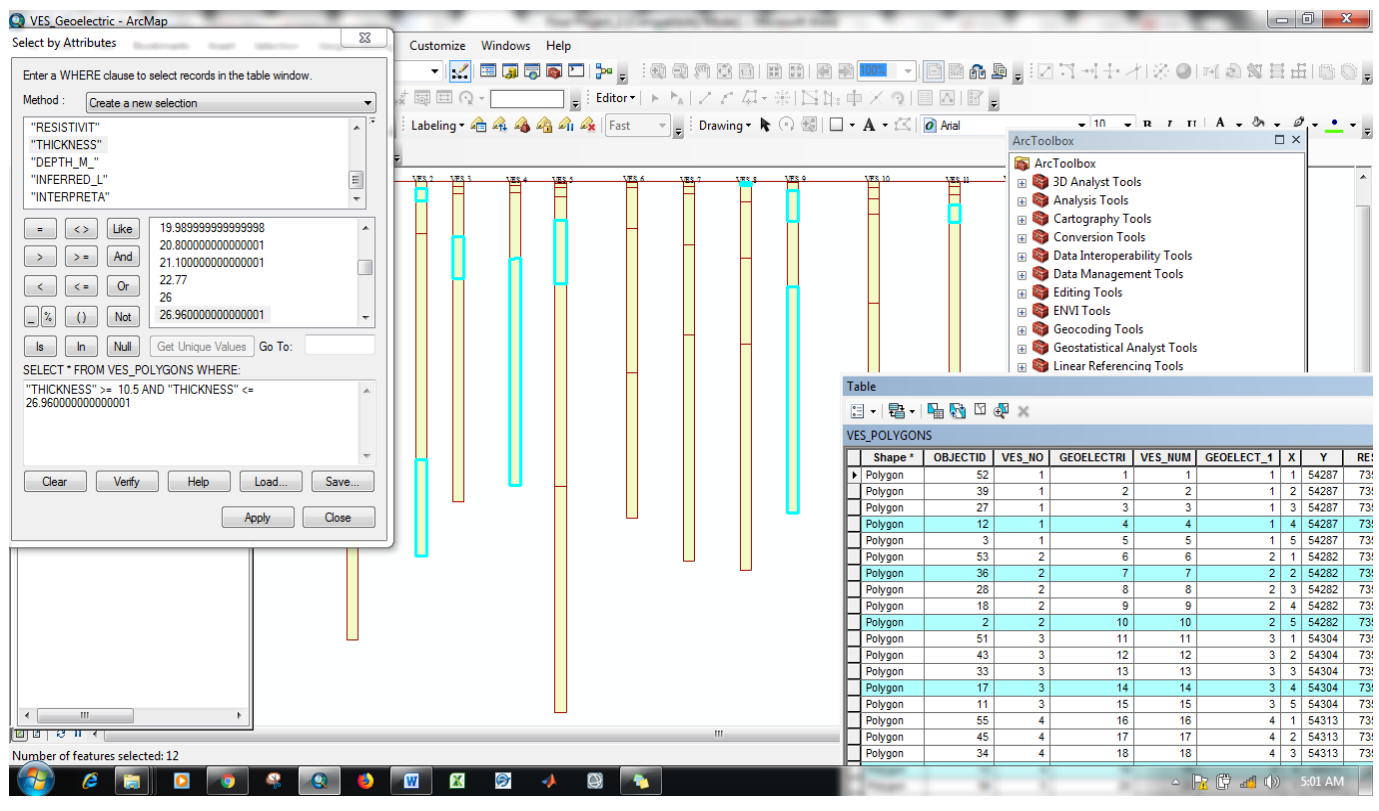

Figure 17: Query performed; "THICKNESS" >= 10.5 AND "THICKNESS"<= 26.960000000000001. (This highlights layers whose thickness is between 10.5 and 26.9.)

\subsection{Discussion}

The ground water potential zones map given in Figure 10 show that $47 \%$ of the total study area (Ogun state) lie within the very high potential zone, $15 \%$ of the area falls within the high, $30 \%$ lies within the of moderate zone, $5 \%$ lies within the low potential zone while and $2 \%$ very low potential zone as shown in Figure 11. The very high potential areas are mainly concentrated along the Alluvial deposit zone of the lower part of the study area. While the "very low potential" prospect zone lies within the area with dominant granite and gneiss deposits (the basement complex zone) of the study area.

Four different formations were found in the interpreted VES data. They are: top soil, sand, clay sand and clay formations respectively. The sand formations contain fresh water suitable for domestic use. Fresh water is generally characterized by having low concentrations of dissolved salts and other total 
dissolved solids. Though the term specifically excludes seawater and brackish water, it does include mineral-rich waters such as chalybeate springs. The database Query showed that the fresh groundwater are available in the following VES points and defined depths :VES 1 (200m), VES 2 $(200 \mathrm{~m})$, VES $3(4.5 \mathrm{~m})$, VES $5(21.3 \mathrm{~m})$, VES $6(35.6)$, VES $7(6.68 \mathrm{~m}, 200 \mathrm{~m})$, VES $8(14.4,200 \mathrm{~m})$, VES $9(5.4 \mathrm{~m})$, VES $10(10.23 \mathrm{~m})$ and VES $11(9.24 \mathrm{~m})$ respectively. However, VES 1, 2, 7 and 8 has fresh water formation at infinite depth and as such possesses the capacity for recharge based on thickness. Brackish water was found in the clay sand formation. Brackish water is the result of the mixing of seawater with fresh water, hence, not suitable for human consumption. Six VES point: 1, 2, 4, 5, 8 and 10 possess layers that have brackish groundwater (clay sand formation) in them. Saline water is water that contains a high concentration of dissolved salts (mainly $\mathrm{NaCl}$ ). The database Query showed that the saline groundwater was found in the clay formation at VES points 1, 2, 3, 4, 5, $6,7,11$ and 12 respectively. This is an indication of possible salt water intrusion within the study area. The query shows that all the VES points have saline water but at different depths except VES 1 . The spatial analysis using GIS showed that the cumulative frequency and cumulative depth of soil types are defined as follows: clay $(28,1567.72 \mathrm{~m})$, sand $(15,625.26 \mathrm{~m})$, clayey sand $(7,186.15 \mathrm{~m})$ and top soil $(12,40.05 \mathrm{~m})$ respectively.

\subsection{Conclusion}

From the ground water potential map obtained, the study area is located at a place of very high ground water potential. Integrated use of Remote Sensing, GIS and Hydrogeophysics for delineation of the groundwater potential zones in this study proved efficient in terms of minimizing cost, time, and labor. The result depicts the groundwater potential zones in the study area and found to be helpful in better planning and management of groundwater resources and also demonstrate that the integration of Remote Sensing, and GIS provide a powerful tool in the assessment and management of water resources and development of groundwater exploration plans.

Integration of different data layers such as Remote Sensing, geomorphology and field data in a GIS environment provide means to unravel the nature of hard rock aquifers. Spatial and statistical analysis allows to understand the correlation between different parameters. In a developing state like Ogun state with weak infrastructure as well as scarce information/data, finding from this study is a good tool which enables policy makers for quick decision-making in sustainable water resources management, suitable for groundwater exploration. The result can also serve as guidelines to determine the region or zone with no water or polluted aquifer.

\section{References}

Adeoti, L, Alile, O. M, Uchegbulam, O. and Adegbola, R. B. (2012). Geoelectrical Investigation of the Groundwater Potential in Mowe, Ogun State, Nigeria. British Journal of Applied Science \& Technology, 2(1): 58-71.

Adiat, K. A. N, Nawawi, M. N. M, Abdullah, K. (2012). Assessing the accuracy of GIS-based elementary multi criteria decision analysis as a spatial prediction tool-A case of predicting potential zones of sustainable ground water resources. J Hydrol, 440-441:75-89

Avtar, R, Singh, C. K, Shashtri, S, Singh, A, Mukherjee, S. (2010). Identification and analysis of groundwater potential zones in Ken-Betwa river linking area using remote sensing and geographic information system. Geocarto Int. 25(5):379-396

Ayedun, H., Taiwo, A. M., Umar, B. F., Oseni, O. A., Oderinde, A. A. (2011). Assessment of groundwater contamination by toxic metals in Ifo, Southwestern Nigeria, Indian Journal of Science and Technology, 4(7):820 - 820. 
Bera, K., \& Bandyopadhyay, J. (2012). Ground water potential mapping in Dulung watershed using remote sensing \& GIS techniques, West Bengal, India. International Journal of Scientific and Research Publications, 2(12), 1-7.

Epuh, E. E, Sanni, K. A., \& Orji, M. J. (2018). Application of Remote Sensing, GIS and Hydrogeophysics to Groundwater exploration in parts of Lagos Metropolis: A case study of Oshodi/Isolo LGA. Nigerian Journal of Environmental Sciences and Technology (NIJEST). 2(1), 4155

Fetter, C. W. (1994). Applied hydrogeology, 4th edn. Prentice Hall, Englewood Cliffs, pp 543-591

Freeze, R. A., \& Cherry, J. A. (1979). Groundwater: Englewood. In: New Jersey, Prentice-Hall Inc., TIC.

Godebo, T. R. (2005). Application of remote sensing and GIS for geological investigation and groundwater potential zone identification, Southeastern Ethiopian Plateau, Bale Mountains and the surrounding areas. Addis A Baba University.

Haridas, V. R., Aravindan, S. \& Girish, Gopinath (1998). Remote sensing and its applications for ground water favorable area identification. Quat. Jour. GARC, 6:18-22.

Javed, A., \& Wani, M. H. (2009). Delineation of groundwater potential zones in Kakund watershed, Eastern Rajasthan, using remote sensing and GIS techniques. Journal of the Geological Society of India, 73(2), 229-236.

Jones, H. A., \& Hockey, R. D. (1964). The Geology of Part of South-western Nigeria: Explanation of 1: 250, Ooo Sheets Nos. 59 and 68. Geological Survey of Nigeria.

Kamaraju, M. V. V., Bhattacharya, A., Reddy, G. S., Rao, G. C., Murthy, G. S., \& Rao, T. C. M. (1996). Ground-Water Potential Evaluation of West Godavari District, Andhra Pradesh State, IndiaA GIS Approach. Groundwater, 34(2), 318-325.

Krishnamurthy, J., Venkatesa Kumar, N., Jayaraman, V., \& Manivel, M. J. (1996). An approach to demarcate ground water potential zones through Remote Sensing and a geographical information system. 17(10), 1867-1884.

Lubang, B., Nobert, J., \& Mtalo, E. G. (2008). Integrated remote sensing and GIS techniques for groundwater exploration in semi-arid region: A Case of Karamoja Region-Uganda. Tanzania Journal of Engineering and Technology, 2(2), 31-42.

Madan, K, J., Chowdary, V. M., Chowdhury, A. (2010). Ground water assessment in Salboni Block, West Bengal (India) using remote sensing, geographical information system and multi-criteria decision analysis techniques. Hydrogeol J 18(7):1713-1728

Makinde, V, Eruola, A.O., Ganiyu, S.A., Olurin, O.T., Adeleke, O.O., Aikhuele, D.O. (2016). Evaluation of Groundwater Potential of Odeda Local Government Area, Ogun State, Southwest Nigeria, J. Nat. Sci. Engr. \& Tech., 15(1): 70-81.

Mallick, J., Singh, C. K., Al-Wadi, H., Ahmed, M., Rahman, A., Shashtri, S., \& Mukherjee, S. (2015). Geospatial and geostatistical approach for groundwater potential zone delineation. Hydrological Processes, 29(3), 395-418.

Moss, R., Moss, G. E. (1990). Handbook of ground water development. Wiley-Interscience, New York, pp 34-51

Mukherjee, P., Singh, C. K., Mukherjee, S. (2012). Delineation of groundwater potential zones in arid region of India - a remote sensing and GIS approach. Water Resour Manag. 26(9):2643-2672

Okogbue, C.O. and Omonona, O.V. (2013). Groundwater potential of Egbe-Mopa basement area, central Nigeria. Hydrological Sciences Journal, 58 (4), 826-840. 
Sajikumar, N., \& Pulikkottil, G. (2013). Integrated remote sensing and GIS approach for groundwater exploration using analytic hierarchy process (AHP) technique. International Journal of Innovative Research in Science, Engineering and Technology, 2(1), 66-74.

Saraf, A., \& Choudhury, P. J. (1998). Integrated Remote Sensing and GIS for groundwater exploration and identification of artificial recharge sites. 19(10), 1825-1841.

Scanlon, B. R., Reddy, R. C., Stonestrom, D. A., Prudic, D. E., Dennehy, K. F. (2005). Impact of land use and land cover change on groundwater and quality in the southwestern US. Glob Chang Biol. 11:1577-1593

Sener, E., Davraz, A., \& Ozcelik, M. (2005). An integration of GIS and Remote Sensing in groundwater investigations: a case study in Burdur, Turkey. 13(5-6), 826-834.

Sreedhar, G., Kumar, G. T., Krishna, I. V., Ercan, K., Cüneyd, D. M. (2009). Mapping of ground water potential zones in the Musi basin using remote sensing data and GIS. Adv Eng Softw. 40:506518

Verbesselt, J., Jonsson, P., Lhermitte, S., Aardt, J., Coppin, P. (2006). Evaluating satellite and climate data-derived indices as fire risk indicators in savanna ecosystems. IEEE Trans Geosci Remote Sens. 44(6):1622-1631

Verma, A. K., Singh, T. N. (2013). Prediction of water quality from simple field parameters. Environ Earth Sci. 69(3):821-829

\section{Cite this article as:}

Epuh E.E., Jimoh N.O, Orji M.J. and Daramola O.E., 2019. Application of Remote Sensing, GIS and Hydrogeophysics to Groundwater Exploration in Ogun State: A case study of OGD-Sparklight Estate. Nigerian Journal of Environmental Sciences and Technology, 3(2), pp. 370-385. https://doi.org/10.36263/nijest.2019.02.0159 